\title{
PENGARUH ZAKAT TERHADAP KONSUMSI RUMAH TANGGA MUSTAHIK (STUDI PADA PENERIMA ZAKAT DARI BAZNAS KOTA PROBOLINGGO)
}

\author{
Elok Nurlita \\ Ilmu Ekonomi, Fakultas Ekonomi dan Bisnis \\ Universitas Brawijaya \\ Email: elok.nurlita@gmail.com \\ Marlina Ekawaty \\ Ilmu Ekonomi, Fakultas Ekonomi dan Bisnis \\ Universitas Brawijaya \\ Email: marlina@ub.ac.id
}

\section{ARTICLE HISTORY \\ Received: \\ 27 Oktober 2017 \\ Accepted:}

20 December 2017

Online available:

25 February 2018

\section{Keywords:}

Poverty,

Consumptive

Zakat, Productive

Zakat, Household

Consumption,

BAZNAS

Probolinggo

Municipality

Kata Kunci:

Kemiskinan, Zakat

Konsumtif, Zakat

Produktif,

Konsumsi Rumah

Tangga, BAZNAS

Kota Probolinggo.

\section{ABSTRACT}

This article aims to analyze the effect of zakat directly and indirectly on household consumption of mustahik. The approach of this research is quantitative. Data obtained from 50 mustahik (receiver of zakat) BAZNAS Probolinggo Municipality with Proportional Random Sampling method and analyzed by Path Analysis. The results showed that zakat and the number of household members directly and indirectly affect the household consumption of mustahik. Furthermore, household income as an intermediate variable also affects the household consumption of mustahik, whereas education and age have no effect on the household consumption of mustahik, either directly or indirectly.

ABSTRAK
Artikel ini bertujuan untuk menganalisis pengaruh zakat
secara langsung dan tidak langsung terhadap konsumsi rumah
tangga mustahik. Pendekatan penelitian ini adalah kuantitatif.
Data diperoleh dari 50 mustahik (penerima zakat) BAZNAS Kota
Probolinggo dengan metode Proportional Random Sampling dan
dianalisis menggunakan analisis jalur (Path Analysis). Hasil
penelitian menunjukkan bahwa zakat dan jumlah anggota
rumah tangga berpengaruh secara langsung dan tidak langsung
terhadap konsumsi rumah tangga mustahik. Selain itu,
pendapatan rumah tangga sebagai variabel perantara juga
berpengaruh terhadap konsumsi rumah tangga mustahik,
sedangkan pendidikan dan usia tidak berpengaruh terhadap
konsumsi rumah tangga mustahik, baik secara langsung maupun
tidak langsung.

\section{ABSTRAK}

secara langsung dan tidak langsung terhadap konsumsi rumah tangga mustahik. Pendekatan penelitian ini adalah kuantitatif. Data diperoleh dari 50 mustahik (penerima zakat) BAZNAS Kota Probolinggo dengan metode Proportional Random Sampling dan dianalisis menggunakan analisis jalur (Path Analysis). Hasil penelitian menunjukkan bahwa zakat dan jumlah anggota rumah tangga berpengaruh secara langsung dan tidak langsung terhadap konsumsi rumah tangga mustahik. Selain itu, pendapatan rumah tangga sebagai variabel perantara juga berpengaruh terhadap konsumsi rumah tangga mustahik, sedangkan pendidikan dan usia tidak berpengaruh terhadap tidak langsung. 
Pengaruh Zakat Terhadap Konsumsi Rumah Tangga ...

\section{PENDAHULUAN}

Konsumsi adalah pembelanjaan barang dan jasa oleh rumah tangga. Konsumsi rumah tangga merupakan penggerak perekonomian di banyak negara, termasuk Indonesia. Hal ini bisa dilihat dari dominannya kontribusi konsumsi rumah tangga dalam pembentukan pendapatan nasional Indonesia. Perbandingan kontribusi setiap komponen pengeluaran dalam Produk Domistik Bruto (PDB) Indonesia tahun 2016 dapat dilihat dari tabel 1 berikut.

Tabel 1

Produk Domestik Bruto Menurut Pengeluaran atas Dasar Harga Berlaku Tahun 2016

\begin{tabular}{llrc}
\hline No. & \multicolumn{1}{c}{ Jenis Pengeluaran } & $\begin{array}{c}\text { Jumlah (Milyar } \\
\text { Rupiah) }\end{array}$ & $\begin{array}{c}\text { Persentase } \\
\text { Terhadap PDB }\end{array}$ \\
\hline 1 & Pengeluaran Konsumsi Rumah Tangga & $7.009 .577,50$ & 56,50 \\
2 & Pengeluaran Konsumsi LNPRT & $144.470,14$ & 1,16 \\
3 & Pengeluaran Konsumsi Pemerintah & $1.172 .420,34$ & 9,45 \\
& Pembentukan Modal Tetap Domestik & $404.0497,83$ & 32,57 \\
4 & Bruto & $214.104,70$ & 1,73 \\
5 & Perubahan Inventori & $2.367 .331,78$ & 19,08 \\
6 & Ekspor Barang dan Jasa & $2.271 .177,86$ & 18,31 \\
\hline 7 & Dikurangi: Impor Barang dan Jasa & $12.406 .809,80$ & 100,00 \\
\hline
\end{tabular}

Sumber: BPS, 2017 (Data Diolah)

Tabel 1 menunjukkan bahwa dibandingkan jenis pengeluaran yang lain, konsumsi rumah tangga memberikan kontribusi terbesar dalam pembentukan Produk Domistik Bruto (PDB) Indonesia yaitu mencapai 56,50\%. Mengingat porsinya yang besar, maka konsumsi rumah tangga memiliki pengaruh yang besar terhadap stabilitas perekonomian. Berbeda dengan konsumsi pemerintah yang bersifat eksogenus, konsumsi rumah tangga bersifat endogenus, artinya besarnya konsumsi rumah tangga berkaitan erat dengan faktor-faktor yang memengaruhinya sehingga dapat disusun teori dan model ekonomi yang menghasilkan pemahaman tentang hubungan tingkat konsumsi dengan faktor-faktor yang memengaruhinya (Rahardja dan Manurung, 2008). Konsumsi rumah tangga dilakukan oleh semua rumah tangga, baik kaya maupun miskin. Jumlah penduduk miskin Indonesia pada September 2016 mencapai 27.764.320 jiwa (BPS, 2017). Jumlah nominal penduduk miskin tersebut sebanyak jumlah penduduk Malaysia. Berdasarkan Peraturan Presiden Republik Indonesia Nomor 15 Tahun 2010 tentang Percepatan Penanggulangan Kemiskinan, sudah banyak program yang dilakukan pemerintah untuk mengurangi jumlah penduduk miskin, diantaranya program bantuan sosial terpadu berbasis keluarga, program penanggulangan kemiskinan berbasis pemberdayaan masyarakat, program penanggulangan kemiskinan berbasis pemberdayaan usaha ekonomi mikro dan kecil, 
serta program-program lainnya yang baik secara langsung ataupun tidak langsung dapat meningkatkan kegiatan ekonomi dan kesejahteraan masyarakat miskin.

Badan Pusat Statistik (BPS) menggunakan konsep kemampuan memenuhi kebutuhan dasar (basic needs approach) untuk mengukur kemiskinan. Dengan pendekatan ini, kemiskinan dipandang sebagai ketidakmampuan dari sisi ekonomi untuk memenuhi kebutuhan dasar makanan dan bukan makanan yang diukur dari sisi pengeluaran konsumsi rumah tangga. Jadi Penduduk Miskin adalah penduduk yang memiliki rata-rata pengeluaran perkapita perbulan di bawah garis kemiskinan.

Dalam hal pembangunan manusia, Islam memiliki suatu instrumen yang sangat potensial untuk menyelesaikan masalah kemiskinan, yaitu zakat, dengan sasaran yang paling utama ialah masyarakat fakir dan miskin. Zakat merupakan bagian dari harta dengan persyaratan tertentu yang diwajibkan oleh Allah SWT kepada pemiliknya untuk diserahkan kepada yang berhak menerimanya, dengan persyaratan tertentu pula (Hafidhuddin, 2002). Allah berfirman dalam Surat AtTaubah ayat 60,

"Sesungguhnya zakat itu hanyalah untuk orang-orang fakir, orang-orang miskin, amil zakat, yang dilunakkkan hatinya (mualaf), untuk (memerdekakan) hamba sahaya, untuk (membebaskan) orang yang berutang, untuk jalan Allah, dan untuk orang yang sedang dalam perjalanan, sebagai kewajiban dari Allah. Allah Maha Mengetahui, Mahabijaksana."

Pemberian zakat bertujuan untuk memenuhi kebutuhan dasar masyarakat fakir, miskin, dan ashnaf lainnya. Zakat dianggap mampu mengentaskan kemiskinan karena merupakan sarana yang dilegalkan oleh agama dalam pembentukan modal. Pembentukan modal tidak hanya berasal dari pengolahan dan pemanfaatan sumber daya alam, tetapi juga dapat melalui upaya penyisihan sebagian harta masyarakat yang mampu untuk diberikan kepada yang berhak menerimanya. Zakat dapat memaksimalkan kualitas Sumber Daya Manusia (SDM) melalui pengadaan sarana dan prasarana bagi masyarakat, meningkatkan produktifitas, serta meningkatkan pendapatan masyarakat secara umum (Amalia, 2012). Apabila zakat dikelola dengan baik dan amanah, maka akan meningkatkan kesejahteraan umat, meningkatkan etos kerja, serta menjadi sarana pemerataan ekonomi masyarakat.

Potensi zakat untuk menyelesaikan masalah kemiskinan ternyata belum sepenuhnya direalisasikan karena masih banyak masyarakat Muslim yang menyalurkan dananya tidak melalui lembaga resmi sehingga pencatatannya tidak tepat. Masyarakat cenderung menyalurkan zakat secara pribadi sehingga zakat yang diterima oleh mustahik hanya digunakan untuk keperluan konsumsi sesaat dan tidak mendatangkan nilai tambah (value added). Seharusnya zakat yang diberikan oleh muzakki (pembayar zakat) tidak hanya disalurkan sebagai dana konsumtif, tetapi juga dalam bentuk dana produktif seperti pemberian modal usaha. Dalam hal ini dibutuhkan adanya lembaga pengelola zakat yang dapat menjadi intermediasi untuk 
Pengaruh Zakat Terhadap Konsumsi Rumah Tangga ...

menyalurkan sebagian harta masyarakat yang mampu kepada masyarakat yang membutuhkan.

Badan Amil Zakat Nasional (BAZNAS) merupakan lembaga pengelola zakat yang secara resmi dibentuk oleh pemerintah untuk mengelola dana zakat masyarakat mulai tingkat nasional, provinsi, sampai tingkat kabupaten/kota. Selain mengelola dana zakat, BAZNAS juga mengelola dana infak/sedekah. Salah satu Badan Amil Zakat Nasional yang berada di tingkat kabupaten/kota ialah BAZNAS Kota Probolinggo. BAZNAS Kota Probolinggo secara resmi berdiri serta mengelola dana zakat dan infak/sedekah (ZIS) sejak tahun 2012 dengan mengutamakan kredibilitas kinerja, akuntabilitas manajemen, serta pengelolaan keuangan yang transparan dan akuntabel. Dana yang dihimpun tahun 2016 mencapai Rp 1.604.059.000 (BAZNAS Kota Probolinggo, 2016).

Jumlah dan persentase penduduk Muslim Kota Probolinggo sangat besar, yakni sebanyak 215.185 jiwa atau 97\% dari jumlah penduduk, sehingga berpotensi besar dalam meningkatkan jumlah dana zakat yang terkumpul. Banyaknya penduduk Muslim Kota Probolinggo dan besarnya dana zakat yang terhimpun di BAZNAS Kota Probolinggo berpotensi menurunkan jumlah penduduk miskin. Jumlah penduduk miskin Kota Probolinggo tahun 2015 sebanyak 18.370 jiwa (BPS Kota Probolinggo, 2016).

Kajian-kajian tentang dampak zakat terhadap konsumsi sudah pernah dilakukan, di antaranya penelitian yang dilakukan oleh Pambudi (2013) terhadap penerima zakat produktif dari BAZNAS Kabupaten Kebumen menunjukkan bahwa zakat produktif berpengaruh secara signifikan terhadap penghasilan, konsumsi, tabungan, dan infak mustahik. Penelitian yang dilakukan oleh Suprayitno dkk (2013) di Malaysia menunjukkan bahwa zakat yang didistribusikan memiliki dampak pada konsumsi agregat, namun dampaknya sangat kecil walaupun secara teoritis menyatakan bahwa kecenderungan konsumsi mustahik lebih besar daripada muzakki. Dampak kecil dari distribusi zakat pada konsumsi mungkin disebabkan oleh digunakannya data konsumsi agregat umat Muslim dan non-Muslim, sementara zakat yang terkumpul didistribusikan untuk memenuhi kebutuhan umat Muslim saja. Penelitian-penelitian tersebut hanya menganalisis pengaruh zakat terhadap konsumsi secara langsung, padahal zakat juga memiliki pengaruh secara tidak langsung terhadap konsumsi melalui pendapatan. Zakat produktif yang didistribusikan berupa modal usaha akan menambah faktor produksi berupa modal (capital) dalam kegiatan usaha mustahik sehingga dapat meningkatkan output dan pendapatan mustahik. Pada akhirnya kenaikan pendapatan ini akan meningkatkan konsumsi rumah tangga mustahik. 
Nurlita dan Ekawaty |Jurnal Ekonomi dan Bisnis Islam, Vol. 3, No. 2, Juli-Des 2017

\section{LANDASAN TEORI}

\section{Teori Konsumsi}

Konsumsi ialah setiap perilaku seseorang untuk menggunakan/memanfaatkan barang dan jasa dalam memenuhi kebutuhan hidupnya (Sumar'in, 2013). Pengeluaran konsumsi terdiri dari konsumsi pemerintah dan konsumsi rumah tangga/masyarakat, namun pada pembahasan ini hanya dijelaskan mengenai pengeluaran konsumsi rumah tangga. Pengeluaran konsumsi rumah tangga adalah nilai perbelanjaan yang dilakukan oleh rumah tangga untuk membeli berbagai jenis kebutuhannya dalam periode tertentu, atau dalam analisis makroekonomi lebih lazim disebut dengan konsumsi rumah tangga (Sukirno, 2011). Rahardja dan Manurung (2008) menjelaskan teori konsumsi yang diajukan oleh John Maynard Keynes. Teori ini biasanya disebut Keynesian Consumption Model. Menurut Keynes, konsumsi saat ini dipengaruhi oleh pendapatan disposabel saat ini, sehingga berlaku fungsi $C=f(Y)$, di mana konsumsi dipengaruhi oleh pendapatan, namun ada batasan konsumsi minimum yang tidak tergantung pada tingkat pendapatan. Artinya, tingkat konsumsi harus dipenuhi walaupun tingkat pendapatan sama dengan 0 . Hal ini disebut konsumsi otonom (autonomous consumption). Apabila pendapatan disposabel meningkat maka konsumsi juga akan meningkat, namun peningkatan konsumsi tidak sebesar peningkatan pendapatan disposabel sehingga berlaku persamaan berikut.

$$
C=a+b Y d
$$

$\mathrm{C}=$ konsumsi (consumption)

$\mathrm{a}=$ konsumsi otonom

$b=$ kecenderungan mengonsumsi marginal (MPC) $(0 \leq b \leq 1)$

$\mathrm{Yd}=$ pendapatan disposabel

Lebih lanjut, Rahardja dan Manurung (2008) memaparkan beberapa faktor yang memengaruhi pengeluaran konsumsi rumah tangga, antara lain adalah pendapatan rumah tangga, kekayaan rumah tangga, jumlah barang konsumsi tahan lama dalam masyarakat, tingkat bunga, perkiraan tentang masa depan, kebijakan pemerintah mengurangi kesenjangan distribusi pendapatan, jumlah dan komposisi penduduk (usia, pendidikan, dan wilayah tinggal), serta faktor sosial budaya.

\section{Teori Konsumsi Islam}

Iqbal (1985) menjelaskan teori konsumsi Islam yang dikemukakan oleh Ausaf dan Metwally bahwa MPC mustahik lebih tinggi daripada muzakki sehingga MPC, APC, dan konsumsi agregat dalam ekonomi Islam akan lebih tinggi daripada ekonomi sekuler. Dimulai dari fungsi konsumsi Keynes: $C_{S}=a+b Y$ dalam ekonomi sekuler. Untuk memperoleh fungsi konsumsi agregat, penduduk dibagi menjadi dua kelompok yaitu muzakki (pembayar zakat) dan mustahik (penerima zakat). Muzakki mentransfer proporsi tertentu $(\alpha)$ dari pendapatannya kepada mustahik karena pungutan wajib zakat, sehingga fungsi konsumsi dalam ekonomi Islam menjadi: 
Pengaruh Zakat Terhadap Konsumsi Rumah Tangga ...

$$
C_{1}=a+b(\beta Y-\alpha Y)+\delta[(1-\beta) Y+\alpha Y]
$$

$C$ adalah fungsi konsumsi yang merupakan fungsi dari pendapatan muzakki dan mustahik. Pendapatan muzakki ditunjukkan pada persamaan ( $\beta Y-\alpha Y$ ), di mana pendapatan muzakki bersih adalah pendapatan muzakki ( $\beta Y$ ) dikurangi dengan zakat $(\alpha \mathrm{Y})$ yang dibayar. Pendapatan mustahik ditunjukkan pada persamaan $[(1-\beta) Y+\alpha Y]$, di mana pendapatan mustahik bersih adalah pendapatan mustahik [(1 - $\beta) Y]$ ditambah dengan zakat $(\alpha \mathrm{Y})$ yang diterima.

Pada model persamaan di atas zakat diperlakukan tidak sama dengan pajak, melainkan diperlakukan sebagai salah satu pengeluaran konsumsi masyarakat untuk akhirat walaupun zakat yang dikeluarkan tersebut dapat berguna bagi sosial kemasyarakatan. Model persamaan konsumsi di atas menggunakan model Absolute Income Hypothesis yang dikemukakan oleh Metwally. Menurut hipotesis ini konsumsi seseorang tergantung sepenuhnya kepada pendapatan saat ini. Hal ini sejalan dengan teori yang ada, yakni mustahik dalam konsumsinya sangat bergantung pada besaran pendapatan yang diterimanya saat ini (Al-Arif, 2010).

Lebih lanjut, Iqbal (1985) menjelaskan model yang diajukan oleh Darwish dan Zain untuk memperbaiki kesalahan teknis yang dikemukakan oleh Ausaf dan Metwally, bahwa untuk mempelajari pengaruh zakat tidak seharusnya dimulai dengan fungsi konsumsi ekonomi sekuler seperti $C=a+b Y$ yang kemudian membaurkannya untuk ekonomi Islam karena dalam fungsi ini "b" menunjukkan MPC kedua kelompok (muzakki dan mustahik). Agar memiliki perbedaan yang berarti, harus dimulai dengan fungsi berikut:

$$
C_{S}=a+c(\beta Y)+d(1-\beta) Y
$$

di mana, c dan d adalah MPC masing-masing kelompok muzakki dan mustahik, sehingga fungsi/model yang sesuai dalam ekonomi Islam adalah:

\section{Peran Zakat dalam Perekonomian}

$$
C_{1}=a+c[\beta Y-\alpha Y]+d[(1-\beta) Y+\alpha Y]
$$

Zakat memiliki peran penting dalam mengurangi kemiskinan. Hal ini sejalan dengan firman Allah SWT dalam surat At-Taubah ayat 60 bahwa sasaran utama zakat ialah untuk golongan fakir dan miskin. Golongan ini memiliki tingkat pendapatan yang lebih kecil daripada kebutuhan atau konsumsinya. Fakir adalah orang yang tidak memiliki harta dan pekerjaan, sehingga tidak mampu untuk mencukupi kebutuhan dasarnya dan kebutuhan dasar orang-orang yang menjadi tanggungannya, sedangkan miskin adalah orang yang memiliki harta dan pekerjaan, namun belum dapat mencukupi kebutuhan dasar dirinya dan orang-orang yang menjadi tanggungannya.

Dalam konteks ekonomi mikro, zakat menjadi sarana untuk memenuhi kebutuhan dan meningkatkan pendapatan mustahik. Sedangkan dalam konteks ekonomi makro, zakat menjadi sarana distribusi pendapatan untuk menghilangkan kesenjangan ekonomi antara masyarakat ekonomi kelas atas dengan masyarakat ekonomi kelas bawah. Apabila pengelolaan zakat dilakukan secara sistematis dan terorganisasi dengan baik maka akan memberikan efek pengganda (multiplier effect) 
Nurlita dan Ekawaty |Jurnal Ekonomi dan Bisnis Islam, Vol. 3, No. 2, Juli-Des 2017

yang besar terhadap peningkatan pendapatan nasional karena terjadi percepatan sirkulasi uang dalam perekonomian suatu negara (Nasrullah, 2010). Hal ini sejalan dengan ayat dan Hadits berikut.

"Perumpamaan orang yang menginfakkan hartanya di jalan Allah seperti sebutir biji yang menumbuhkan tujuh tangkai, pada setiap tangkai ada seratus biji. Allah melipatgandakan (ganjaran) bagi siapa yang Dia kehendaki, dan Allah Mahaluas (kurnia-Nya), Maha Mengetahui." (QS Al-Baqarah: 261)

"Dari Ibnu Abbas RA meriwayatkan dari Rasulullah SAW, beliau bersabda menyampaikan apa yang diterimanya dari Tuhannya, Allah azza wa jalla. 'Sesungguhnya Allah menetapkan kebaikan dan keburukan kemudian menjelaskannya; barangsiapa berniat melakukan kebaikan dan tidak jadi melakukannya, maka Allah mencatat di sisi-Nya sebagai satu kebaikan yang sempurna. Jika ia berniat melakukan kebaikan lalu ia benar-benar melakukannya maka Allah akan mencatat di sisi-Nya sepuluh kebaikan sampai tujuh ratus kali lipat bahkan masih dilipatgandakannya lagi. Jika ia berniat melakukan keburukan tetapi tidak jadi melakukan maka Allah mencatatnya sebagai satu kebaikan. Dan jika ia berniat melakukan keburukan lalu ia benar-benar melakukannya, maka Allah hanya mencatat di sisi-Nya satu keburukan.'" (HR Bukhari dan Muslim)

Ayat dan Hadits di atas menggambarkan secara implisit efek pengganda zakat. Berdasarkan ayat dan Hadits tersebut dapat dijelaskan mekanisme efek pengganda zakat, di mana dalam hal ini diasumsikan bantuan zakat diberikan dalam bentuk konsumtif. Zakat dalam bentuk bantuan konsumtif yang diberikan kepada mustahik akan meningkatkan daya beli mustahik tersebut terhadap suatu barang yang menjadi kebutuhannya. Peningkatan daya beli terhadap suatu barang akan berpengaruh pada peningkatan produksi suatu perusahaan. Dampak dari peningkatan produksi adalah penambahan kapasitas produksi yang berarti perusahaan akan menyerap tenaga kerja lebih banyak. Sementara itu peningkatan produksi akan meningkatkan pajak yang dibayarkan perusahaan kepada negara. Jika penerimaan negara bertambah, maka negara akan mampu menyediakan sarana dan prasarana untuk pembangunan serta mampu menyediakan fasilitas publik bagi masyarakat (Al-Arif, 2010).

Zakat berperan dalam memutar roda perekonomian secara terus menerus dan tidak boleh berhenti. Zakat menjadi instrumen untuk mengatasi masalah sosioekonomi masyarakat kelas bawah yang kebutuhan hidupnya harus dipenuhi seketika dan dalam jangka pendek. Zakat merupakan faktor pendorong (push factor) dalam perbaikan kondisi masyarakat, khususnya dalam hal ekonomi karena melalui distribusi zakat akan terjadi pertumbuhan kesejahteraan masyarakat yang lebih luas. Apabila zakat dikelola dengan baik dan benar seperti yang dicontohkan oleh Nabi Muhammad SAW maka akan meningkatkan kesejahteraan masyarakat, mengurangi pengangguran, serta mengurangi jumlah masyarakat fakir dan miskin (Khasanah, 2010). 
Pengaruh Zakat Terhadap Konsumsi Rumah Tangga ...

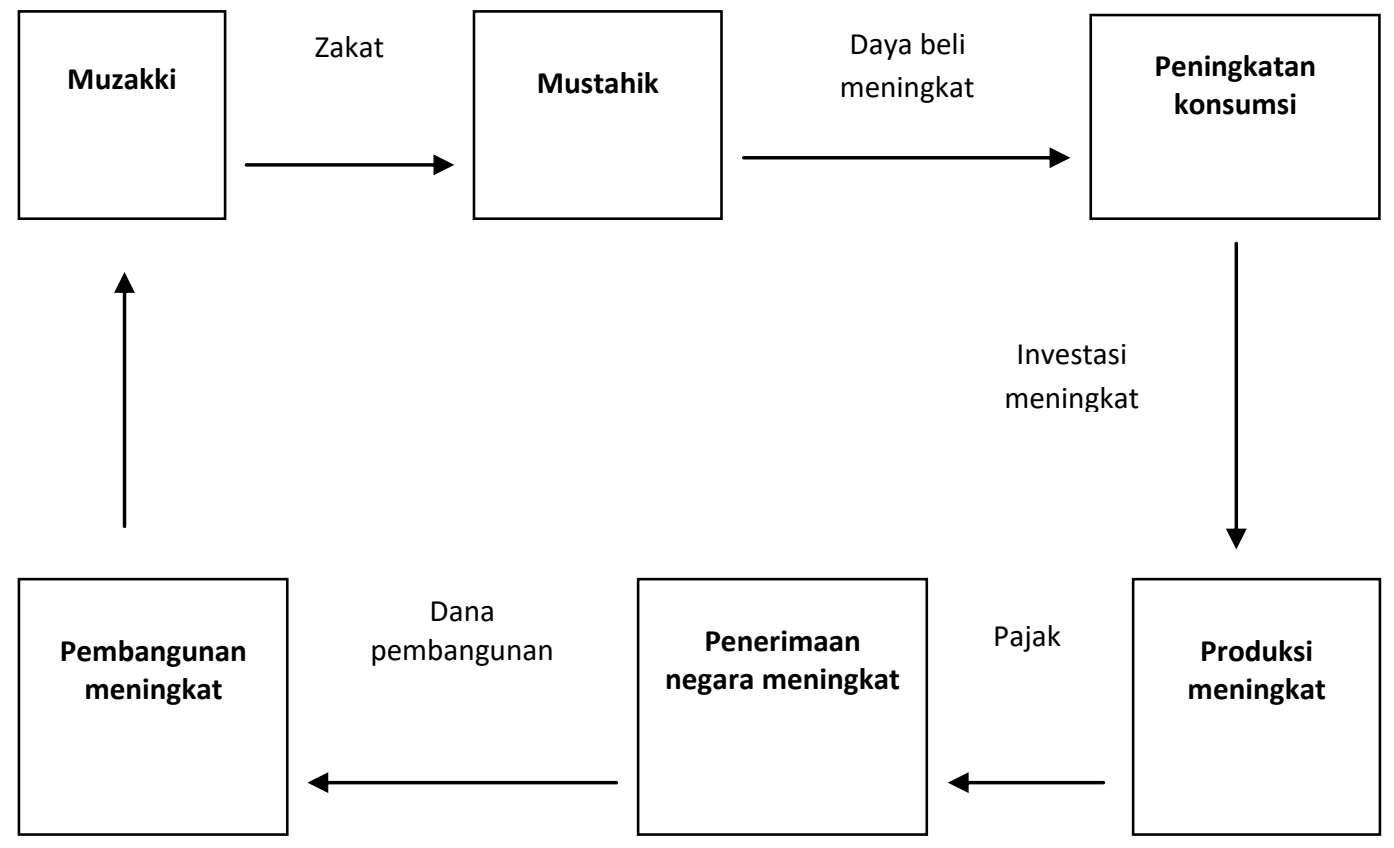

Sumber: Al-Arif (2010)

Gambar 1. Efek Pengganda Zakat dalam Perekonomian

Gambar di atas menunjukkan bahwa pembayaran dana zakat mampu menghasilkan efek yang berlipat ganda (multiplier effect) dalam perekonomian yang pada akhirnya berdampak secara tidak langsung bagi masyarakat. Zakat yang disalurkan dalam bentuk bantuan konsumtif saja telah mampu memberikan efek pengganda yang signifikan, apalagi diberikan dalam bentuk bantuan produktif seperti modal usaha atau dana bergulir, tentu akan menghasilkan efek pengganda yang lebih besar dalam suatu perekonomian karena zakat dalam bentuk bantuan produktif memberikan efek yang lebih besar daripada zakat dalam bentuk bantuan konsumtif (Nasrullah, 2010). Zakat yang disalurkan kepada orang-orang yang membutuhkan akan memberikan pengaruh lebih besar pada permintaan agregat (aggregate demand) karena kebutuhan konsumsi golongan ini relatif lebih besar, akan tetapi perlu disadari bahwa peran strategis zakat akan terwujud apabila kaum Muslim benar-benar meyakini dan menunaikan zakat dengan benar. Selain itu, perlu ditanamkan keyakinan yang kuat tentang pentingnya kewajiban zakat, baik dalam rangka menjalin hubungan vertikal dengan Allah SWT, maupun mewujudkan kesejahteraan secara adil dalam kehidupan masyarakat (Hayati, 2009).

Berdasarkan penjelasan di atas dapat disimpulkan bahwa zakat memiliki peran penting dalam perekonomian, baik secara mikro maupun makro, baik dalam bentuk bantuan konsumtif maupun produktif, serta bagi muzakki dan muztahik. Oleh karena itu pengelolaan zakat secara profesional, amanah, dan transparan perlu ditingkatkan guna meningkatkan pembangunan ekonomi dan kesejahteraan masyarakat. 


\section{METODE PENELITIAN}

Penelitian ini menggunakan pendekatan kuantitatif. Pengumpulan data dilakukan sejak Maret hingga Mei 2017 di Kota Probolinggo. Metode pengumpulan data dilakukan dengan cara wawancara, pengisian kuesioner, dan dokumentasi. Subjek penelitian ini adalah mustahik BAZNAS Kota Probolinggo sebagai responden utama dan pengurus BAZNAS Kota Probolinggo sebagai responden pendukung. Populasi dalam penelitian ini adalah seluruh mustahik BAZNAS Kota Probolinggo dari ashnaf fakir dan miskin, baik penerima zakat konsumtif maupun zakat produktif yang berjumlah 100 orang. Teknik sampling yang digunakan adalah Proportional Random Sampling. Sampel yang dibutuhkan dalam penelitian ini sebanyak 50 orang, dengan jumlah sampel masing-masing golongan penerima zakat konsumtif dan produktif adalah 16 orang dan 34 orang. Untuk mengetahui pengaruh langsung dan tidak langsung zakat terhadap konsumsi rumah tangga mustahik digunakan analisis jalur (Path Anaysis). Model persamaan struktural yang digunakan dalam analisis jalur ini ada 2, yaitu jalur I dan jalur II.

$$
\begin{array}{ll}
Y_{1}=a_{1} X_{1}+a_{2} X_{2}+a_{3} X_{3}+a_{4} X_{4}+a_{5} e_{1} & \text { (Jalur I) } \\
Y_{2}=b_{1} X_{1}+b_{2} X_{2}+b_{3} X_{3}+b_{4} X_{4}+b_{5} Y_{1}+b_{6} e_{2} & \text { (Jalur II) }
\end{array}
$$

$Y_{1}=$ pendapatan (pendapatan rumah tangga)

$\mathrm{Y}_{2}=$ konsumsi (konsumsi rumah tangga)

$\mathrm{X}_{1}=$ zakat yang diterima

$X_{2}=$ jumlah anggota rumah tangga

$\mathrm{X}_{3}=$ pendidikan (pendidikan kepala rumah tangga)

$\mathrm{X}_{4}=$ usia (usia kepala rumah tangga)

$\mathrm{e}_{1}, \mathrm{e}_{2}=$ eror

$a_{1-4}, b_{1-5}=$ koefisien jalur

$a_{5}, b_{6}=$ koefisien residu.

Persamaan struktural jalur I bertujuan untuk menganalisis pengaruh variabel eksogen, yaitu zakat yang diterima, jumlah anggota rumah tangga, pendidikan, dan usia terhadap variabel perantara, yaitu pendapatan. Adapun persamaan struktural jalur II bertujuan untuk menganalisis pengaruh variabel eksogen, yaitu zakat yang diterima, jumlah anggota rumah tangga, pendidikan, usia, dan pendapatan terhadap variabel endogen, yaitu konsumsi. Hasil estimasi dianalisis menggunakan uji asumsi analisis jalur (uji normalitas dan uji linieritas), uji validitas model (koefisien determinasi total dan uji keseluruhan model), serta uji signifikansi (koefisien determinasi, uji F, dan uji t). 
Pengaruh Zakat Terhadap Konsumsi Rumah Tangga ...

\section{HASIL DAN PEMBAHASAN}

\section{Gambaran Umum Badan Amil Zakat Nasional Kota Probolinggo}

Badan Amil Zakat Nasional (BAZNAS) Kota Probolinggo merupakan lembaga yang memiliki tugas mengumpulkan, mendistribusikan, dan mendayagunakan dana zakat, infak, dan sedekah di Kota Probolinggo. Kantor BAZNAS Kota Probolinggo terletak di Gedung Islamic Centre Lantai 2, Jalan Basuki Rahmad, Kota Probolinggo, Jawa Timur.

Berdasarkan Undang-Undang Nomor 38 Tahun 1999 tentang Pengelolaan Zakat, maka dibentuklah tim kecil untuk melengkapi regulasi tentang Badan Amil Zakat yang membentuk RAPERDA tentang Pengelolaan Zakat sehingga tahun 2010 PERDA Nomor 11 Tahun 2010 tentang Pengelolaan Zakat disahkan oleh Dewan Perwakilan Rakyat Daerah. Menindaklanjuti regulasi di atas, maka dikeluarkan Surat Keputusan Walikota Probolinggo Nomor 188.45/84/KEP/425.012/2011 tentang Pengurus Badan Amil Zakat Nasional (BAZNAS) Kota Probolinggo. Hal ini menjadi cikal bakal berdirinya BAZNAS Kota Probolinggo. Setelah terbentuk pengurus, maka dilakukan pemetaan potensi muzakki dan mustahik pada masing-masing kelurahan serta sosialisasi pada masing-masing Satuan Kerja dan pada lembaga pendidikan selama kurang lebih 1 tahun. Selanjutnya pada bulan Mei 2012 "Gerakan Sadar Zakat" diresmikan oleh walikota Probolinggo (BAZNAS Kota Probolinggo, 2016).

\section{Hasil Estimasi}

Dengan bantuan program Statistical Product and Service Solution (SPSS), ringkasan hasil estimasi model persamaan struktural untuk jalur I dan II ditunjukkan pada tabel berikut:

Tabel 2

Hasil Estimasi Analisis Jalur

\begin{tabular}{|c|c|c|c|c|c|c|c|}
\hline \multicolumn{3}{|c|}{ Jalur I } & \multicolumn{5}{|c|}{ Jalur II } \\
\hline $\begin{array}{c}\text { Variabel } \\
\text { Bebas }\end{array}$ & $\begin{array}{c}\text { Standar- } \\
\text { dized Coeffi- } \\
\text { cients Beta }\end{array}$ & $\mathbf{T}$ & Sig. $t$ & $\begin{array}{c}\text { Variabel } \\
\text { Bebas }\end{array}$ & $\begin{array}{c}\text { Standar- } \\
\text { dized Coeffi- } \\
\text { cients Beta }\end{array}$ & $\mathbf{t}$ & Sig. $t$ \\
\hline $\mathrm{X}_{1}$ & 0,263 & 1,777 & $0,082^{* *}$ & $\mathrm{x}_{1}$ & 0,193 & 1,839 & $0,073 * *$ \\
\hline$x_{2}$ & 0,367 & 2,327 & $0,025^{*}$ & $x_{2}$ & 0,554 & 4,844 & $0,000 *$ \\
\hline$x_{3}$ & $-0,285$ & $-1,526$ & 0,134 & $x_{3}$ & 0,015 & 0,114 & 0,910 \\
\hline \multirow[t]{2}{*}{$\mathrm{X}_{4}$} & $-0,134$ & $-0,732$ & 0,468 & $x_{4}$ & $-0,051$ & $-0,403$ & 0,689 \\
\hline & & & & $Y_{1}$ & 0,225 & 2,198 & $0,033^{*}$ \\
\hline \multicolumn{4}{|c|}{ Variabel Terikat: $Y_{1}$} & \multicolumn{4}{|c|}{ Variabel Terikat: $Y_{2}$} \\
\hline \multicolumn{4}{|c|}{$F=3,286 ;$ Sig. $F=0,019 ; R^{2}=0,226$} & \multicolumn{4}{|c|}{$F=15,920 ;$ Sig. $F=0,000 ; R^{2}=0,664$} \\
\hline \multicolumn{8}{|c|}{ *: Signifikan pada tingkat 0,05} \\
\hline \multicolumn{8}{|c|}{ **: Signifikan pada tingkat 0,10 } \\
\hline
\end{tabular}


Nurlita dan Ekawaty |Jurnal Ekonomi dan Bisnis Islam, Vol. 3, No. 2, Juli-Des 2017

Sumber: Hasil Analisis Data, 2017

Sebelum dilakukan analisis terhadap hasil estimasi tersebut, perlu dilakukan uji asumsi analisis jalur.

\section{Uji Asumsi Analisis Jalur}

Berdasarkan salah satu asumsi yang mendasari path analysis, yaitu hubungan antarvariabel bersifat normal dan linier (Riduwan dan Kuncoro, 2011), maka perlu dilakukan uji normalitas dan linieritas dalam melakukan analisis jalur. Pengujian normalitas dilakukan dengan uji Kolmorogov-Smirnov (K-S), sedangkan uji linieritas dilihat dari nilai sig. pada Deviation from Linearity. Ringkasan hasil uji normalitas dan linieritas dapat dilihat pada tabel berikut.

Tabel 3

Hasil Uji Asumsi Analisis Jalur

\section{Uji Normalitas}

\begin{tabular}{|c|c|c|c|}
\hline \multicolumn{2}{|c|}{ Jalur I } & \multicolumn{2}{|c|}{ Jalur II } \\
\hline $\begin{array}{l}\text { Asymp. Sig. (2- } \\
\text { tailed) }\end{array}$ & 0,166 & $\begin{array}{c}\text { Asymp. Sig. (2- } \\
\text { tailed) }\end{array}$ & 0,971 \\
\hline \multicolumn{4}{|c|}{ Uji Linieritas } \\
\hline \multicolumn{2}{|c|}{ Jalur I } & \multicolumn{2}{|c|}{ Jalur II } \\
\hline \multirow[t]{3}{*}{ Variabel } & Nilai Sig. pada & Variabel & Nilai Sig. pada \\
\hline & Deviation from & & Deviation from \\
\hline & Linearity & & Linearity \\
\hline$X_{1}$ dengan $Y_{1}$ & 0,796 & $X_{1}$ dengan $Y_{2}$ & 0,449 \\
\hline$X_{2}$ dengan $Y_{1}$ & 0,224 & $X_{2}$ dengan $Y_{2}$ & 0,557 \\
\hline$X_{3}$ dengan $Y_{1}$ & 0,000 & $X_{3}$ dengan $Y_{2}$ & 0,133 \\
\hline \multirow[t]{2}{*}{$X_{4}$ dengan $Y_{1}$} & 0,772 & $X_{4}$ dengan $Y_{2}$ & 0,523 \\
\hline & & $Y_{1}$ dengan $Y_{2}$ & 0,157 \\
\hline
\end{tabular}

Sumber: Hasil Analisis Data, 2017

Berdasarkan hasil uji normalitas diperoleh nilai Asymp. Sig. (2-tailed) untuk jalur I sebesar 0,166. Nilai Sig. ini lebih besar dari tingkat signifikansi 0,10 ( $\alpha=10 \%$ ). Artinya, residual pada model jalur I terdistribusi normal. Adapun nilai Asymp. Sig. (2tailed) untuk jalur II sebesar 0,971. Nilai Sig. ini juga lebih besar dari tingkat signifikansi $0,10(\alpha=10 \%)$. Artinya, residual pada model jalur II terdistribusi normal.

Dari uji linieritas, dapat dilihat nilai Sig. pada Deviation from Linearity. Pada jalur I, nilai Sig. masing-masing variabel $X_{1}, X_{2}$, dan $X_{4}$ dengan $Y_{1}$ sebesar 0,$796 ; 0,224$; dan 0,772 . Nilai tersebut lebih besar dari tingkat signifikansi $0,10(\alpha=10 \%)$, berarti hubungan antarvariabel adalah linier. Nilai Sig. antara variabel $X_{3}$ dengan $Y_{1}$ sebesar 
Pengaruh Zakat Terhadap Konsumsi Rumah Tangga ...

0,000 yang artinya hubungan antara variabel $X_{3}$ dengan $Y_{1}$ tidak linier. Dapat disimpulkan bahwa hubungan antara variabel eksogen dengan variabel endogen jalur I secara keseluruhan bersifat linier. Pada jalur II, nilai Sig. masing-masing variabel $\mathrm{X}_{1}$, $X_{2}, X_{3}, X_{4}$, dan $Y_{1}$ dengan $Y_{2}$ sebesar 0,$449 ; 0,557 ; 0,133 ; 0,523$, dan 0,157. Nilai Sig. ini lebih besar dari tingkat signifikansi 0,10 ( $\alpha=10 \%)$, berarti hubungan antarvariabel adalah linier. Dapat disimpulkan bahwa hubungan antara variabel eksogen dengan variabel endogen jalur II secara keseluruhan bersifat linier.

\section{Uji Validitas Model}

Pengujian validitas model dilihat dari 2 indikator, yaitu koefisien determinasi total dan uji keseluruhan model. Hasil uji validitas dapat dilihat pada tabel berikut:

Tabel 4

Hasil Uji Validitas Model

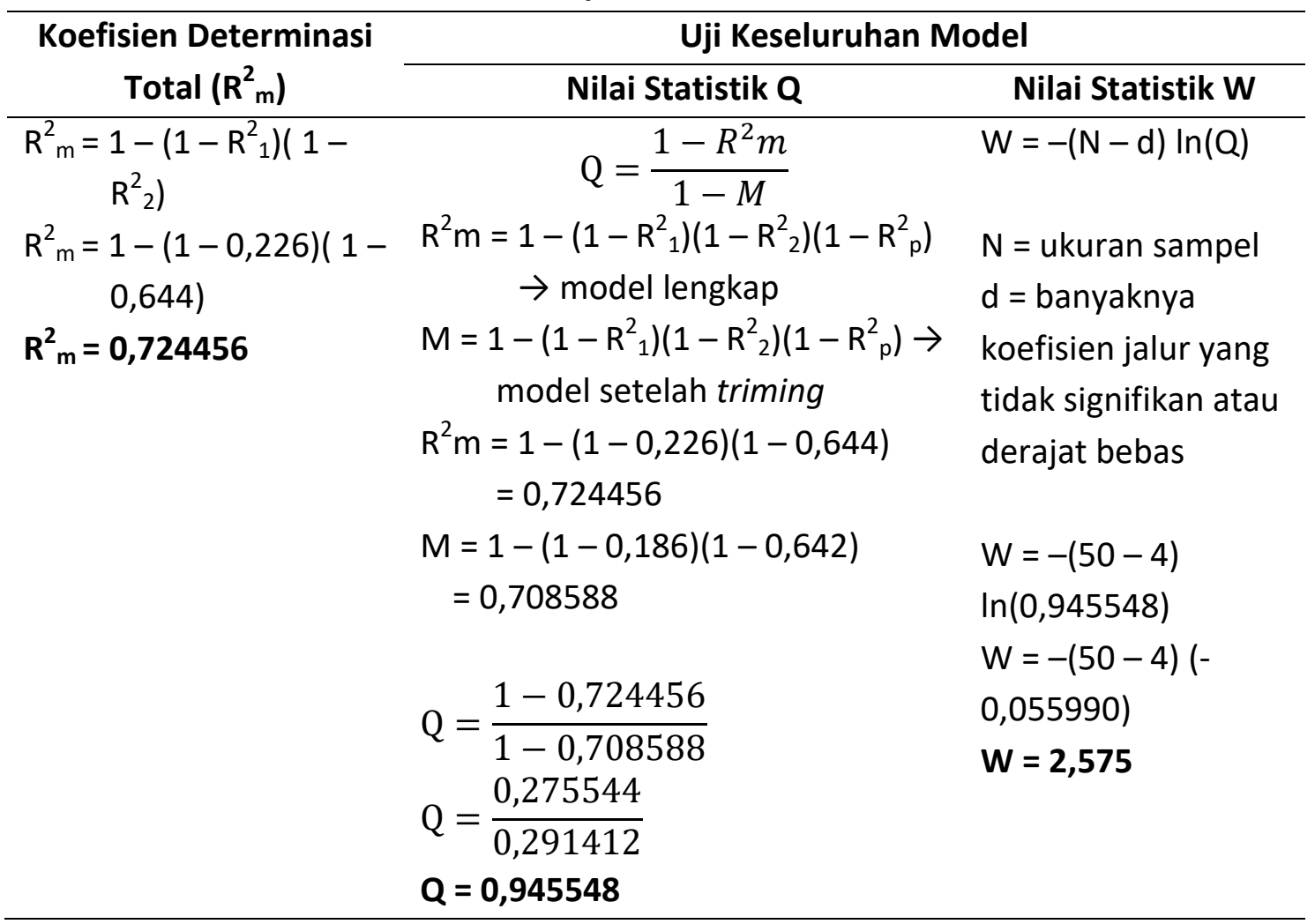

Sumber: Hasil Analisis Data, 2017

Nilai koefisien determinasi total adalah 0,724456. Artinya, keragaman data yang dapat dijelaskan oleh model analisis jalur, baik jalur I maupun jalur II sebesar 0,724 atau dengan kata lain variasi variabel konsumsi $72,4 \%$ dapat dijelaskan oleh variabel zakat yang diterima, jumlah anggota rumah tangga, pendidikan, usia, dan pendapatan, sedangkan sisanya dijelaskan oleh faktor lain yang tidak terdapat dalam model. Nilai statistik $Q$ sebesar 0,945 menunjukkan nilai yang tinggi karena $Q$ mendekati 1 sehingga dapat dikatakan bahwa model memiliki tingkat kecocokan yang tinggi dengan data. Adapun nilai Chi-Square tabel dengan derajat bebas 4 dan $\alpha=$ $10 \%$ adalah 7,78 . Karena nilai statistik $W(2,575)<$ Chi-Square tabel $(7,78)$ berarti 
Nurlita dan Ekawaty |Jurnal Ekonomi dan Bisnis Islam, Vol. 3, No. 2, Juli-Des 2017

model yang diajukan cocok dengan data empiris. Berdasarkan hasil tersebut, dapat disimpulkan bahwa model analisis jalur ini, baik jalur I maupun jalur II adalah valid.

\section{Uji Signifikansi}

Pengujian signifikansi dilakukan untuk menganalisis pengaruh variabelvariabel eksogen terhadap variabel endogen secara simultan dan parsial/individual. Dasar pengujian menggunakan nilai signifikansi $0,1(\alpha=10 \%)$. Hasil analisis pengaruh variabel-variabel eksogen terhadap variabel endogen dapat dilihat pada tabel 2.

\section{a. Jalur I (Pendapatan Sebagai Variabel Endogen)}

Pengujian secara simultan (uji F) jalur I dilakukan untuk mengetahui pengaruh zakat yang diterima $\left(X_{1}\right)$, jumlah anggota rumah tangga $\left(X_{2}\right)$, pendidikan $\left(X_{3}\right)$, dan usia $\left(X_{4}\right)$ terhadap pendapatan $\left(Y_{1}\right)$ secara bersama-sama. Pengaruh $X_{1}, X_{2}, X_{3}$, dan $X_{4}$ secara simultan terhadap $Y_{1}$ dapat dilihat dari nilai Sig. $F$, yaitu sebesar 0,019 yang lebih kecil dari nilai signifikansi 0,10. Dengan demikian disimpulkan bahwa zakat yang diterima, jumlah anggota rumah tangga, pendidikan, dan usia secara simultan berpengaruh signifikan terhadap pendapatan. Nilai koefisien determinasi $\left(R^{2}\right)$ sebesar 0,226 artinya variabel zakat yang diterima, jumlah anggota rumah tangga, pendidikan, dan usia mampu menjelaskan perubahan variabel pendapatan sebesar $22,6 \%$, sedangkan sisanya dijelaskan oleh faktor/variabel lain yang tidak dibahas dalam penelitian ini. Adapun besarnya koefisien residu adalah $a_{5}=\sqrt{1-0,226}=$ 0,879 .

Pengujian secara parsial (uji t) jalur I dilakukan untuk mengetahui pengaruh zakat yang diterima $\left(X_{1}\right)$, jumlah anggota rumah tangga $\left(X_{2}\right)$, pendidikan $\left(X_{3}\right)$, dan usia $\left(X_{4}\right)$ terhadap pendapatan $\left(Y_{1}\right)$ secara individual. Uji $t$ dapat dilihat dari nilai Sig. $t$ masing-masing variabel bebasnya. Pengaruh zakat yang diterima $\left(X_{1}\right)$ secara parsial terhadap pendapatan $\left(Y_{1}\right)$ sebesar 0,263 dengan nilai Sig. $t$ sebesar 0,082 yang lebih kecil dari nilai signifikansi 0,10 . Pengaruh jumlah anggota rumah tangga $\left(\mathrm{X}_{2}\right)$ secara parsial terhadap pendapatan $\left(Y_{1}\right)$ sebesar 0,367 dengan nilai Sig. t sebesar 0,025 yang lebih kecil dari nilai signifikansi 0,10 . Pengaruh pendidikan $\left(X_{3}\right)$ secara parsial terhadap pendapatan $\left(Y_{1}\right)$ sebesar -0,285 dengan nilai Sig. $t$ sebesar 0,134 yang lebih besar dari nilai signifikansi 0,10 . Pengaruh usia $\left(X_{4}\right)$ secara parsial terhadap pendapatan $\left(Y_{1}\right)$ sebesar $-0,134$ dengan nilai Sig. $t$ sebesar 0,468 yang lebih besar dari nilai signifikansi 0,10. Dapat disimpulkan bahwa zakat yang diterima dan jumlah anggota rumah tangga secara parsial berpengaruh signifikan terhadap pendapatan, sedangkan pendidikan dan usia secara parsial tidak berpengaruh signifikan terhadap pendapatan.

Hasil di atas menunjukkan bahwa pada jalur I secara simultan zakat yang diterima $\left(X_{1}\right)$, jumlah anggota rumah tangga $\left(X_{2}\right)$, pendidikan $\left(X_{3}\right)$, dan usia $\left(X_{4}\right)$ berpengaruh signifikan terhadap pendapatan $\left(Y_{1}\right)$. Secara parsial, ada koefisien jalur yang tidak signifikan, yaitu pendidikan $\left(\mathrm{X}_{3}\right)$ dan usia $\left(\mathrm{X}_{4}\right)$ maka jalur I perlu diperbaiki 
Pengaruh Zakat Terhadap Konsumsi Rumah Tangga ...

melalui Metode Triming, yakni mengeluarkan variabel $\mathrm{X}_{3}$ dan $\mathrm{X}_{4}$ dari persamaan I dan melakukan estimasi kembali tanpa variabel $X_{3}$ dan $X_{4}$. Hasilnya ditunjukkan pada tabel berikut.

Tabel 5

Hasil Estimasi Jalur I Setelah Metode Triming

\begin{tabular}{|c|c|c|c|c|c|c|}
\hline & \multirow[t]{2}{*}{ Model } & \multicolumn{2}{|c|}{$\begin{array}{l}\text { Unstandardized } \\
\text { Coefficients }\end{array}$} & \multirow{2}{*}{$\begin{array}{c}\text { Standardized } \\
\text { Coefficients }\end{array}$} & \multirow[t]{2}{*}{$\mathbf{t}$} & \multirow[t]{2}{*}{ Sig. } \\
\hline & & B & Std. Error & & & \\
\hline \multirow[t]{3}{*}{1} & (Constant) & -323127.418 & 642662.954 & & -.503 & .617 \\
\hline & $X_{1}$ & 1.031 & .612 & .236 & 1.685 & $.099 * *$ \\
\hline & $X_{2}$ & 324083.260 & 156144.327 & .290 & 2.076 & $.043^{*}$ \\
\hline \multicolumn{3}{|c|}{ a. Dependent Variable: $Y_{1}$} & $F=5.369$ & Sig. $F=0.008$ & $=0.186$ & \\
\hline
\end{tabular}

*: Signifikan pada tingkat 0,05

**: Signifikan pada tingkat 0,10

Sumber: Hasil Analisis Data, 2017

Berdasarkan hasil estimasi diperoleh nilai koefisien jalur untuk zakat yang diterima sebesar 0,236 dan jumlah anggota rumah tangga sebesar 0,290 dengan koefisien determinasi sebesar $\mathrm{R}^{2}=0,186$ dan koefisien residu sebesar $\mathrm{a}_{5}=$ $\sqrt{1-0,186}=0,902$. Adapun nilai Sig. F sebesar 0,008.

\section{b. Jalur II (Konsumsi Sebagai Variabel Endogen)}

Pengujian secara simultan (uji F) jalur II dilakukan untuk mengetahui pengaruh zakat yang diterima $\left(X_{1}\right)$, jumlah anggota rumah tangga $\left(X_{2}\right)$, pendidikan $\left(X_{3}\right)$, usia $\left(X_{4}\right)$, dan pendapatan $\left(Y_{1}\right)$ terhadap konsumsi $\left(Y_{2}\right)$ secara bersama-sama. Pengaruh $X_{1}, X_{2}$, $X_{3}, X_{4}$, dan $Y_{1}$ secara simultan terhadap $Y_{2}$ dapat dilihat dari nilai Sig. $F$, yaitu sebesar 0,000 lebih kecil dari nilai signifikansi 0,10. Dengan demikian dapat disimpulkan bahwa zakat yang diterima, jumlah anggota rumah tangga, pendidikan, usia, dan pendapatan secara simultan berpengaruh signifikan terhadap konsumsi. Nilai koefisien determinasi $\left(R^{2}\right)$ sebesar 0,664 artinya variabel zakat yang diterima, jumlah anggota rumah tangga, pendidikan, usia, dan pendapatan mampu menjelaskan perubahan variabel konsumsi sebesar $66,4 \%$, sedangkan sisanya dijelaskan oleh faktor/variabel lain yang tidak dibahas dalam penelitian ini. Adapun besarnya koefisien residu adalah $b_{6}=\sqrt{1-0,644}=0,567$.

Pengujian secara parsial (uji t) jalur II dilakukan untuk mengetahui pengaruh zakat yang diterima $\left(X_{1}\right)$, jumlah anggota rumah tangga $\left(X_{2}\right)$, pendidikan $\left(X_{3}\right)$, usia $\left(X_{4}\right)$, dan pendapatan $\left(Y_{1}\right)$ terhadap konsumsi $\left(Y_{2}\right)$ secara individual. Uji t dapat dilihat dari nilai Sig. $t$ masing-masing variabel bebasnya. Pengaruh zakat yang diterima $\left(X_{1}\right)$ secara parsial terhadap konsumsi $\left(Y_{2}\right)$ sebesar 0,193 dengan nilai Sig. $t$ sebesar 0,073 
Nurlita dan Ekawaty |Jurnal Ekonomi dan Bisnis Islam, Vol. 3, No. 2, Juli-Des 2017

yang lebih kecil dari nilai signifikansi 0,10. Pengaruh jumlah anggota rumah tangga $\left(\mathrm{X}_{2}\right)$ secara parsial terhadap konsumsi $\left(\mathrm{Y}_{2}\right)$ sebesar 0,554 dengan nilai Sig. $t$ sebesar 0,000 yang lebih kecil dari nilai signifikansi 0,10 . Pengaruh pendidikan $\left(X_{3}\right)$ secara parsial terhadap konsumsi $\left(\mathrm{Y}_{2}\right)$ sebesar 0,015 dengan nilai Sig. t sebesar 0,910 yang lebih besar dari nilai signifikansi 0,10 . Pengaruh usia $\left(X_{4}\right)$ secara parsial terhadap konsumsi $\left(Y_{2}\right)$ sebesar -0,051 dengan nilai Sig. $t$ sebesar 0,689 yang lebih besar dari nilai signifikansi 0,10 . Pengaruh pendapatan $\left(Y_{1}\right)$ secara parsial terhadap konsumsi $\left(Y_{2}\right)$ sebesar 0,225 dengan nilai Sig. $t$ sebesar 0,033 yang lebih kecil dari nilai signifikansi 0,10. Dapat disimpulkan bahwa zakat yang diterima, jumlah anggota rumah tangga, dan pendapatan secara parsial berpengaruh signifikan terhadap konsumsi, sedangkan pendidikan dan usia secara parsial tidak berpengaruh signifikan terhadap konsumsi.

Hasil di atas menunjukkan bahwa pada jalur II secara simultan zakat yang diterima $\left(X_{1}\right)$, jumlah anggota rumah tangga $\left(X_{2}\right)$, pendidikan $\left(X_{3}\right)$, usia $\left(X_{4}\right)$, dan pendapatan $\left(Y_{1}\right)$ berpengaruh signifikan terhadap konsumsi $\left(Y_{2}\right)$. Secara parsial, ada koefisien jalur yang tidak signifikan, yaitu pendidikan $\left(\mathrm{X}_{3}\right)$ dan usia $\left(\mathrm{X}_{4}\right)$ maka jalur II perlu diperbaiki melalui Metode Triming, yakni mengeluarkan variabel $\mathrm{X}_{3}$ dan $\mathrm{X}_{4}$ dari persamaan II dan melakukan estimasi kembali tanpa variabel $X_{3}$ dan $X_{4}$. Hasilnya ditunjukkan pada tabel berikut.

Tabel 6

Hasil Estimasi Jalur II Setelah Metode Triming

\begin{tabular}{ccccc}
\hline Model & $\begin{array}{c}\text { Unstandardized } \\
\text { Coefficients }\end{array}$ & $\begin{array}{c}\text { Standardized } \\
\text { Coefficients }\end{array}$ & t & Sig.
\end{tabular}

\begin{tabular}{|c|c|c|c|c|c|c|}
\hline & & B & Std. Error & Beta & & \\
\hline \multirow[t]{6}{*}{1} & (Constant & -29781.017 & 187102.71 & & -.159 & .874 \\
\hline & ) & & 5 & & & \\
\hline & $x_{1}$ & .404 & .183 & .213 & 2.209 & $.032^{*}$ \\
\hline & $\mathrm{x}_{2}$ & 280393.88 & 47369.758 & .580 & 5.919 & $.000^{*}$ \\
\hline & & 7 & & & & \\
\hline & $Y_{1}$ & .096 & .042 & .222 & 2.265 & $.028^{*}$ \\
\hline & ndent Var & ble: $Y_{2}$ & $F=27.437$ & $F=0.000$ & $2=0.642$ & \\
\hline
\end{tabular}

*: Signifikan pada tingkat 0,05

Sumber: Hasil Analisis Data, 2017

Berdasarkan hasil estimasi diperoleh nilai koefisien jalur untuk zakat yang diterima sebesar 0,213; jumlah anggota rumah tangga sebesar 0,580; dan pendapatan sebesar 0,222 dengan koefisien determinasi sebesar $R^{2}=0,642$ dan koefisien residu sebesar $b_{6}=\sqrt{1-0,642}=0,598$. Adapun nilai Sig. F sebesar 0,000. 
Pengaruh Zakat Terhadap Konsumsi Rumah Tangga ...

Bentuk persamaan struktural keseluruhan setelah dilakukan metode triming adalah:

$$
\begin{aligned}
Y_{1} & =a_{1} X_{1}+a_{2} X_{2}+a_{5} e_{1} \\
& =0,236 X_{1}+0,290 X_{2}+0,902 e_{1} \\
Y_{2} & =b_{1} X_{1}+b_{2} X_{2}+b_{5} Y_{1}+b_{6} e_{2} \\
& =0,213 X_{1}+0,580 X_{2}+0,222 Y_{1}+0,598 e_{2}
\end{aligned}
$$

Nilai koefisien determinasi total $\left(R_{m}^{2}\right)$ sebesar 0,724456 memiliki arti bahwa kemampuan variabel zakat yang diterima, jumlah anggota rumah tangga, pendidikan, usia, dan pendapatan dalam menjelaskan perubahan variabel konsumsi sebesar $72,4 \%$, sedangkan sisanya dijelaskan oleh faktor atau variabel lain yang tidak dibahas dalam penelitian ini. Secara simultan variabel zakat yang diterima, jumlah anggota rumah tangga, pendidikan, usia, dan pendapatan berpengaruh positif dan signifikan terhadap konsumsi. Berdasarkan hasil perhitungan analisis jalur, besarnya pengaruh langsung, pengaruh tidak langsung, dan pengaruh total kedua model jalur dirangkum dalam tabel berikut ini:

Tabel 7

Rangkuman Pengaruh Langsung, Pengaruh Tidak Langsung, dan Pengaruh Total Variabel Eksogen terhadap Variabel Endogen

\begin{tabular}{lccccc}
\hline Pengaruh Variabel & \multicolumn{3}{c}{ Pengaruh Kausal } & $\mathbf{R}^{2}$ & $\begin{array}{c}\text { Koef. } \\
\text { Residu }\end{array}$ \\
\cline { 2 - 3 } & Langsung & Tidak Langsung & Total & & \\
\hline$X_{1}$ terhadap $Y_{1}$ & 0,236 & & & \\
$X_{2}$ terhadap $Y_{1}$ & 0,290 & - & - & & \\
$X_{3}$ terhadap $Y_{1}$ & - & - & - & & \\
$X_{4}$ terhadap $Y_{1}$ & - & & & 0,186 & 0,902 \\
$X_{1}$ dan $X_{2}$ terhadap & & & & \\
$Y_{1}$ & & & & \\
$X_{1}$ terhadap $Y_{2}$ & 0,213 & $0,236 \times 0,222=0,052$ & 0,265 & & \\
$X_{2}$ terhadap $Y_{2}$ & 0,580 & $0,290 \times 0,222=0,064$ & 0,644 & & \\
$X_{3}$ terhadap $Y_{2}$ & - & - & - & & \\
$X_{4}$ terhadap $Y_{2}$ & - & - & 0,222 & & \\
$Y_{1}$ terhadap $Y_{2}$ & 0,222 & & & 0,642 & 0,598 \\
$X_{1}, X_{2}$ dan $Y_{1}$ & & & & & \\
terhadap $Y_{2}$ & & & & & \\
\hline
\end{tabular}

Sumber: Hasil Analisis Data, 2017

Berdasarkan tabel di atas, maka dapat digambarkan diagram jalur secara keseluruhan sebagai berikut. 


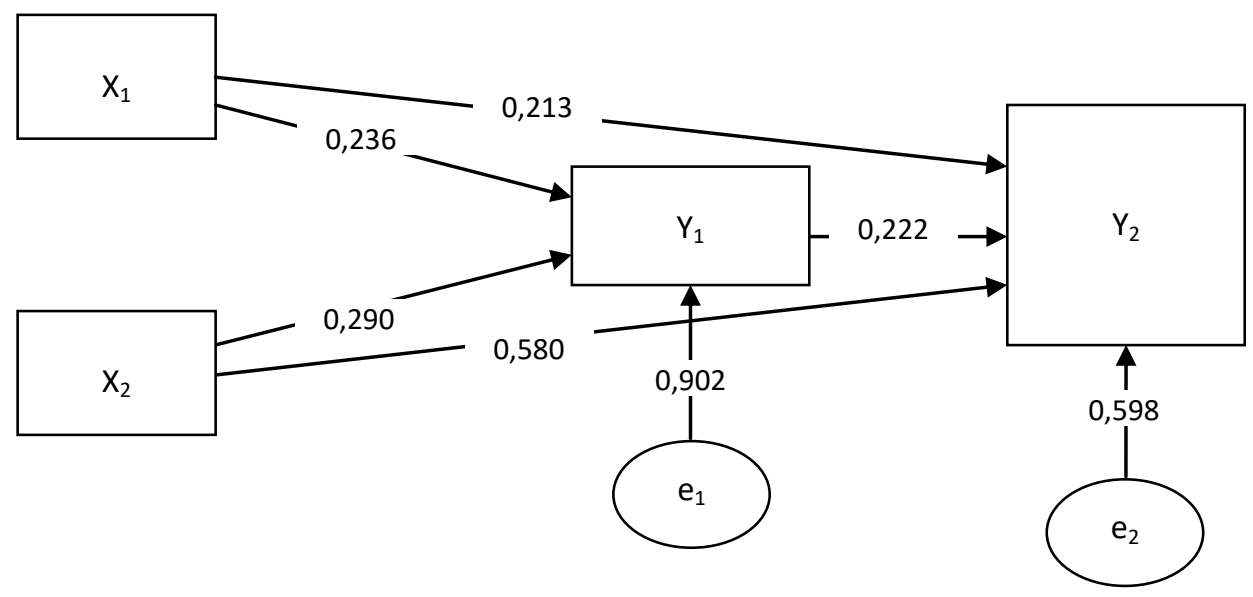

Sumber: Hasil Analisis Data, 2017

Gambar 2. Diagram Jalur

Setelah dilakukan analisis data, dapat diinterpretasikan pengaruh langsung dan tidak langsung zakat yang diterima, jumlah anggota rumah tangga, pendidikan, usia, dan pendapatan terhadap konsumsi. Pendapatan $\left(Y_{1}\right)$ memiliki pengaruh yang signifikan terhadap konsumsi $\left(\mathrm{Y}_{2}\right)$ dan pengaruhnya adalah positif. Artinya, jika pendapatan naik maka konsumsi juga naik. Hasil ini sesuai dengan teori konsumsi Keynes. Menurut Keynes, konsumsi dipengaruhi oleh pendapatan. Ketika pendapatan naik maka konsumsi juga akan naik, tetapi kenaikan konsumsi tidak sebesar kenaikan pendapatan. Koefisien jalur pendapatan terhadap konsumsi sebesar 0,222 artinya ketika terjadi kenaikan pendapatan dalam rumah tangga mustahik (terstandarisasi) sebesar 1 standar deviasi ceteris paribus, maka rata-rata tingkat konsumsi rumah tangga mustahik (terstandarisasi) bertambah sebesar 0,222 standar deviasi.

Zakat yang diterima $\left(\mathrm{X}_{1}\right)$ memiliki pengaruh yang signifikan baik secara langsung maupun tidak langsung terhadap konsumsi $\left(\mathrm{Y}_{2}\right)$ dan pengaruhnya adalah positif. Artinya, jika dana zakat yang diterima mustahik naik maka konsumsi rumah tangganya akan naik. Hasil ini sesuai dengan teori yang menyatakan bahwa ketika zakat yang diterima naik maka konsumsi juga akan naik. Koefisien jalur zakat yang diterima terhadap konsumsi sebesar 0,213 artinya ketika terjadi kenaikan zakat yang diterima (terstandarisasi) sebesar 1 standar deviasi ceteris paribus, maka rata-rata tingkat konsumsi (terstandarisasi) bertambah sebesar 0,213 standar deviasi. Zakat dalam hal ini disalurkan untuk tujuan konsumsi rumah tangga mustahik secara langsung (zakat konsumtif). Zakat yang diterima juga memiliki pengaruh secara tidak langsung terhadap konsumsi melalui pendapatan. Koefisien jalur zakat yang diterima terhadap konsumsi melalui pendapatan sebesar 0,052 artinya ketika terjadi kenaikan zakat yang diterima (terstandarisasi) sebesar 1 standar deviasi ceteris paribus, maka rata-rata tingkat konsumsi (terstandarisasi) bertambah sebesar 0,052 standar deviasi. Zakat dalam hal ini disalurkan untuk tujuan produktif (zakat produktif), yaitu dana zakat digunakan sebagai modal usaha bagi mustahik untuk meningkatkan pendapatannya. Pendayagunaan zakat untuk usaha produktif ini dilakukan apabila 
Pengaruh Zakat Terhadap Konsumsi Rumah Tangga ...

kebutuhan dasar mustahik telah terpenuhi. Zakat produktif ini akan menambah faktor produksi berupa modal (capital) dalam kegiatan usaha mustahik sehingga dapat meningkatkan output dan pendapatannya, pada akhirnya kenaikan pendapatan ini akan meningkatkan konsumsi rumah tangganya. Secara langsung dan tidak langsung pengaruh zakat yang diterima terhadap konsumsi sebesar 0,265.

Hasil tersebut menunjukkan bahwa zakat konsumtif memiliki pengaruh yang lebih besar daripada zakat produktif. Hal ini berbanding terbalik dengan teori yang menyatakan bahwa zakat dalam bentuk bantuan produktif memberikan efek yang lebih besar daripada zakat dalam bentuk bantuan konsumtif. Rendahnya pengaruh zakat produktif daripada zakat konsumtif diperkirakan disebabkan oleh tidak adanya program pendampingan/pembinaan oleh BAZNAS Kota Probolinggo sehingga penggunaan zakat produktif kurang efektif. Sebagian mustahik menggunakan zakat produktif untuk konsumsi sesaat, sebagian mengalami kendala sehingga kegiatan usahanya tidak berjalan sampai saat ini, dan sebagian belum memanfaatkan barang modal yang diterima karena merasa tidak memiliki keahlian. Dari 34 mustahik, hanya 19 mustahik penerima zakat produktif yang kegiatan usahanya masih berjalan sampai saat ini.

Jumlah anggota rumah tangga $\left(X_{2}\right)$ memiliki pengaruh yang signifikan baik secara langsung maupun tidak langsung terhadap konsumsi $\left(Y_{2}\right)$ dan pengaruhnya adalah positif. Artinya, semakin banyak jumlah anggota rumah tangga mustahik maka konsumsi rumah tangganya akan naik. Hasil ini sesuai dengan teori yang menyatakan bahwa ketika jumlah penduduk atau anggota rumah tangga tinggi maka konsumsi juga akan tinggi. Koefisien jalur jumlah anggota rumah tangga terhadap konsumsi sebesar 0,580 artinya ketika jumlah anggota rumah tangga (terstandarisasi) bertambah sebesar 1 standar deviasi ceteris paribus, maka rata-rata tingkat konsumsi (terstandarisasi) bertambah sebesar 0,580 standar deviasi. Jumlah anggota rumah tangga juga memiliki pengaruh secara tidak langsung terhadap konsumsi melalui pendapatan. Koefisien jalur jumlah anggota rumah tangga terhadap konsumsi melalui pendapatan sebesar 0,064 artinya ketika jumlah anggota rumah tangga (terstandarisasi) bertambah sebesar 1 standar deviasi ceteris paribus, maka rata-rata tingkat konsumsi (terstandarisasi) bertambah sebesar 0,064 standar deviasi. Secara langsung dan tidak langsung pengaruh jumlah anggota rumah tangga terhadap konsumsi sebesar 0,644.

Pendidikan $\left(\mathrm{X}_{3}\right)$ tidak berpengaruh signifikan, baik secara langsung maupun tidak langsung terhadap konsumsi $\left(\mathrm{Y}_{2}\right)$. Artinya, tinggi rendahnya tingkat pendidikan kepala rumah tangga mustahik tidak menyebabkan perbedaan terhadap konsumsi rumah tangganya. Hasil ini berbanding terbalik dengan teori yang menyatakan bahwa semakin tinggi pendidikan seseorang maka konsumsinya juga akan tinggi. Penyebab tidak adanya pengaruh pendidikan terhadap konsumsi dapat dikaitkan dengan jenis pekerjaan mustahik. Sebagian besar mustahik (44\%) bekerja sebagai pedagang kecil seperti pedagang ikan, sayur, roti, sembako, dan lain-lain, di mana dalam pekerjaan 
ini tidak dibutuhkan pendidikan/keahlian khusus seperti pendidikan untuk profesi dokter, guru, arsitek, dan tenaga ahli lainnya sehingga tinggi rendahnya tingkat pendidikan tidak memengaruhi pendapatan dan konsumsi rumah tangganya.

Usia $\left(\mathrm{X}_{4}\right)$ tidak berpengaruh signifikan, baik secara langsung maupun tidak langsung terhadap konsumsi $\left(\mathrm{Y}_{2}\right)$. Artinya, bertambahnya usia kepala rumah tangga tidak memengaruhi besarnya konsumsi rumah tangganya. Menurut teori konsumsi Hipotesis Siklus Hidup, pola konsumsi seseorang dibagi menjadi 3 periode. Periode pertama ialah sejak seseorang berusia 0 tahun sampai berusia tertentu, di mana orang tersebut belum dapat menghasilkan pendapatan sendiri. Pada periode ini terjadi dissaving (melakukan konsumsi tetapi tidak menghasilkan pendapatan). Periode kedua ialah saat seseorang telah bekerja (dapat menghasilkan pendapatan sendiri) sampai saat tidak bekerja lagi, di mana saat ini dapat melakukan saving. Kemudian periode terakhir ialah saat seseorang berada pada usia tua dan tidak mampu lagi menghasilkan pendapatan sendiri sehingga mengalami dissaving lagi (Sudarman dan Algifari, 1992). Berdasarkan data hasil penelitian diketahui bahwa mustahik yang berada pada usia tidak produktif (> 64 tahun) sebanyak 18\% dan mustahik yang tidak bekerja juga sebanyak 18\%. Menurut teori, ketika seseorang berada pada usia tua (tidak produktif) dan tidak mampu lagi menghasilkan pendapatan sendiri maka mengalami dissaving sehingga tingkat konsumsinya menurun. Pada bagian ini bertambahnya usia seseorang tidak meningkatkan konsumsi.

\section{SIMPULAN}

Berdasarkan hasil analisis data dan pembahasan, maka dapat ditarik kesimpulan bahwa zakat yang diterima dan jumlah anggota rumah tangga berpengaruh terhadap konsumsi rumah tangga mustahik, baik secara langsung maupun tidak langsung. Selain itu, pendapatan rumah tangga sebagai variabel perantara juga berpengaruh terhadap konsumsi rumah tangga mustahik, sedangkan pendidikan kepala rumah tangga dan usia kepala rumah tangga tidak berpengaruh terhadap konsumsi rumah tangga mustahik, baik secara langsung maupun tidak langsung. Dari kesimpulan tersebut, dapat dikemukakan beberapa saran, antara lain program pemberdayaan melalui zakat produktif diharapkan dapat dilakukan kembali oleh BAZNAS Kota Probolinggo. Diharapkan besarnya dana zakat produktif yang disalurkan untuk masing-masing mustahik dapat ditingkatkan karena zakat produktif mampu meningkatkan pendapatan mustahik sehingga mustahik akan mampu meningkatkan konsumsi rumah tangganya. Selanjutnya, program pendampingan/pembinaan perlu dilakukan minimal 3 bulan sekali untuk mengetahui perkembangan usaha mustahik dan kendala yang dihadapi mustahik. Pendampingan/pembinaan dilakukan supaya penggunaan zakat yang disalurkan lebih efektif sehingga memberi manfaat yang lebih besar bagi mustahik. BAZNAS Kota Probolinggo diharapkan mampu mengakomodasi kebutuhan mustahik yang berkaitan 
Pengaruh Zakat Terhadap Konsumsi Rumah Tangga ...

dengan kegiatan usaha, yakni dalam menyediakan faktor produksi seperti modal, barang-barang produktif (peralatan/mesin), dan keahlian/keterampilan. Dalam hal ini pelatihan kewirausahaan sangat dibutuhkan untuk meningkatkan keahlian mustahik. Mustahik BAZNAS Kota Probolinggo diharapkan dapat menggunakan dana zakat maupun infak/sedekah yang diterima secara efektif dan efisien supaya dana tersebut dapat memberikan manfaat yang besar bagi mustahik secara khusus dan perekonomian secara umum. Mengingat variabel bebas/eksogen dalam penelitian ini merupakan variabel-variabel yang memengaruhi konsumsi, diharapkan hasil penelitian ini dapat menjadi acuan bagi peneliti selanjutnya untuk mengembangkan penelitian ini dengan mempertimbangkan variabel-variabel lain yang belum dibahas dalam penelitian ini.

\section{DAFTAR PUSTAKA}

Al-Arif, M Nur Rianto (2010). Efek pengganda zakat serta implikasinya terhadap program pengentasan kemiskinan. Jurnal Ekbisi Fakultas Syariah UIN Sunan Kalijaga Yogyakarta, 5(1), 42-49.

Amalia, Kasyful Mahalli (2012). Potensi dan peranan zakat dalam mengentaskan kemiskinan di Kota Medan. Jurnal Ekonomi dan Keuangan, 1(1), 70-87.

BAZNAS Kota Probolinggo (2016). Profil BAZNAS Kota Probolinggo. Probolinggo: Penulis.

BPS (2017). Kemiskinan. Diakses dari https://www.bps.go.id/subjek/view/id/23

BPS (2017). Statistik Indonesia, Jakarta: Penulis.

BPS Kota Probolinggo (2016). Kota Probolinggo dalam angka. Probolinggo: Penulis.

Departemen Agama Republik Indonesia (2006). Al-Qur'an dan Terjemahannya. Surabaya: CV Pustaka Agung Harapan.

Hafidhuddin, Didin (2002). Zakat dalam perekonomian modern. Jakarta: Gema Insani Press.

Hayati, Mardhiyah (2009). Peran strategis zakat dalam fungsi kebijakan politik ekonomi di Indonesia. Jurnal TAPIs, 5(10), 37-52.

Iqbal, Munawar (1985). Zakah, Moderation, and Aggregate Consumption in an Islamic Economy. Journal Research Islamic Economics, 3(1), 45-61.

Nasrullah, Muhammad (2010). Peran zakat sebagai pendorong Multiplier Ekonomi. Jurnal Hukum Islam, 8(1), 108-119. 
Nurlita dan Ekawaty |Jurnal Ekonomi dan Bisnis Islam, Vol. 3, No. 2, Juli-Des 2017

Pambudi, Hidayat Aji (2013). Peranan zakat produktif dalam pemberdayaan masyarakat miskin (Studi kasus pada Badan Amil Zakat (BAZ) Kabupaten Kebumen). Fokus Bisnis: Media Pengkajian Manajemen dan Akuntansi, 12(2), 70-82.

Peraturan Presiden Republik Indonesia Nomor 15 Tahun 2010 tentang Percepatan Penanggulangan Kemiskinan. 2010. Diakses dari www.bpkp.go.id/uu/filedownload/5/4/1834.bpkp

Rahardja, Prathama \& Manurung, Mandala (2008). Pengantar Ilmu Ekonomi: Mikroekonomi dan makroekonomi (edisi ketiga). Jakarta: Lembaga Penerbit Fakultas Ekonomi Universitas indonesia.

Riduwan \& Kuncoro, Engkos Achmad (2011). Cara mudah menggunakan dan memaknai Path Analysis (Analisis Jalur). Bandung: Alfabeta.

Sukirno, Sadono (2011). Makroekonomi teori pengantar (edisi ketiga). Jakarta: PT RajaGrafindo Persada.

Sumar'in (2013). Ekonomi Islam: Sebuah pendekatan ekonomi mikro perspektif Islam. Yogyakarta: Graha Ilmu.

Suprayitno, Eko dkk (2013). The impact of Zakat on Aggregate Consumption in Malaysia. Journal of Islamic Economics, Banking, and Finance, 9(1), 39-62.

Umrotul Khasanah (2010). Manajemen zakat modern: Instrumen pemberdayaan ekonomi umat. Malang: UIN-Maliki Press. 